\title{
Employment regulation and productivity: Is there a case for deregulation?
}

\begin{abstract}
This paper explores empirically the economic validity of the relatively limited approach to the regulation of employment protection pursued in the UK over the last three decades and within the European Union more recently. It does so by comparing the UK's manufacturing labour productivity performance with those of three countries - France, Germany and Sweden - that possess more stringent employment protection laws. The findings reveal that while productivity growth in the UK was superior to France and Sweden, it was lower than in Germany. More generally, the study's findings fail to support the existence of a straightforward negative relationship between regulatory stringency and productivity growth.
\end{abstract}

\section{Keywords}

Employment protection, labour productivity, legal regulation, United Kingdom, France, Germany, Sweden 


\section{Employment regulation and productivity: Is there a case for deregulation?}

\section{Introduction}

In the 36 years since Mrs Thatcher's first election victory in 1979 a major theme of employment regulation in the UK has been the creation and maintenance of a regulatory framework that is supportive of enhanced productivity and economic competitiveness, largely on the basis of business defined efficiency needs (Davies and Freedland, 2007; Dickens and Hall, 2003). During this period a prevailing political consensus has emerged that employment regulation, and the social rights encompassed with it, should be framed much more in relation to the need to support employer flexibility and innovativeness, and, in the wider spectrum, enhance economic performance. Even under New Labour, although the rhetoric was significantly different, the dominance of the 'employer-friendly' approach to employment legislation remained unchanged.

This approach to employment regulation, with its emphasis on leaving British employers more lightly regulated than their counterparts in other developed economies, continues to inform current government policy (see e.g. Department for Business Enterprise and Regulatory Reform, 2008). Thus, during the 2010-15 period of Conservative-Liberal Democrat Coalition government a range of reforms were introduced designed to reduce the regulatory burden facing employers. In doing so it argued that a 'key driver of the strong performance of the UK labour market is our light-touch system of employment' and that this system 'is an important element of the UK's competitive advantage (Department for Business Innovation and Skills, 2011). Notable among these reforms have been a number of changes affecting statutory provisions governing unfair dismissal (Ewing and Hendy, 2012; Busby et al, 2013; Hepple, 
2013). For example, the length of continuous employment required to claim unfair dismissal has been extended from one to two years, employer obligations to consult over collective redundancies have been reduced, and a new cap imposed on the compensation that can be awarded in respect of a successful unfair dismissal claim. In addition, reforms to the employment tribunal system have been introduced which have acted to increase the costs and financial risks associated with bringing claims, and provisions have been introduced under which employees can forego a range of employment rights, including in relation to unfair dismissal, in return for shares in their employing company.

The validity of the central economic logic informing these reforms takes on additional policy significance in the context of responses at the level of the European Union (EU) and individual member states to the 2008 economic crises and the related sovereign debt one that commenced in 2010. Thus, while exhibiting some variation across member states, these have been marked by deregulatory labour market actions, notably in those Eurozone economies where strategies of 'internal devaluation have been pursued' (Armingeon and Baccaro, 2012; Barnard, 2012; Heyes, 2011 and 2013; Meardi, 2011). This commonality of response can be seen to be reflective of the emphasis the EU has placed since the 1990s on improving productivity and competiveness via supply side reforms, a focus apparent most notably in the European Employment and Lisbon Strategies (Ball, 2001; Goetschy, 1999). An emphasis that can in turn be noted to itself reflect the influence of policies of labour market liberalisation promulgated by bodies like the OECD (1994) and World Bank (2008) (see e.g. Casey, 2004). ${ }^{1}$

These policies remain politically controversial, as the ongoing debates between the social partners over how far the flexicurity policy of the European Commission encompasses a focus on 'job', as opposed to 'employment', security illustrates (see e.g. Heyes, 2013). 
Meanwhile, there remains considerable uncertainty as to whether labour regulation does in fact serve to hinder employment growth and economic performance more generally, with the result that it remains very much open to question how far the deregulatory policies advocated by policymakers are empirically supported. Indeed, the OECD itself has published contradictory conclusions on the issue. For example, on the basis of a 2006 reassessment of its 1994 jobs strategy the OECD concluded that 'there is evidence that too_-strict [employment protection] legislation [EPL] will hamper labour mobility, reduce the dynamic efficiency employment of the economy and restrain job creation' (OECD, 2006: 212). Yet in the assessment referred to it is noted that 'the impact of EPL and union density on unemployment are statistically insignificant' and that there was support for the view that 'in centralised/coordinated bargaining systems, unions and employers are able to internalise the adverse employment consequences of excessive wage claims' (2006: 212). ${ }^{2}$

Against this background of apparent international policy consensus, but empirical uncertainty, the present paper therefore sets out to further test empirically the view that a comparatively limited approach to employment protection is conducive to enhanced economic competitiveness. More specifically, it provides an empirical analysis aimed at exploring whether the performance of UK manufacturing firms in terms of labour productivity has been superior to those in three comparable countries, France, Germany and Sweden, which have more extensive systems of employment protection.

The remainder of the paper proceeds as follows. Initially, existing theory and empirical findings relating to the relationship between employment regulation and productivity are reviewed and discussed. Following this, the methodology of the empirical analysis undertaken is both justified and outlined, and its findings subsequently reported. Finally, these findings are discussed theoretically in relation to existing research evidence and the light they shed on the 
proposition that extensive employment protection arrangements are harmful to economic performance in general and productivity in particular.

\section{Theoretical background}

Within the general equilibrium framework of neo-classical economics, conditions of perfect competition are seen, via price driven forces of supply and demand, to bring together the selfinterested motives of individual actors, thereby ensuring that resources gravitate to where they can be most productively employed. In a world of zero transaction costs, regulatory interventions in labour markets are seen to hinder this spontaneous process of interest coalescence (Epstein, 1984). Consequently, regulation is prime facie considered harmful to social welfare in general and productivity more particularly (Coase, 1988).

Nevertheless, neo-classical theorists do not completely discount a potentially beneficial role for market regulation. It is recognised that the effective operation of markets as social institutions depends on norms and conventions that enable market actors to coordinate their activities on the basis of a set of mutually supportive expectations. Although these norms and conditions, such as those relating to private property rights and the enforcement of contracts, evolve informally (and endogenously), it is acknowledged that the formal law can potentially play a productive role in supporting them and overcoming associated lock-in effects and other features of path dependency (see e.g. Sugden, 1989).

Those working within the neo-classical paradigm also commonly acknowledge that employment laws can help address market failures, including imperfect and asymmetric information, employer monopsony power, and the presence of externalities and public goods 
that can distort the operation of labour markets, thereby leading to the inefficient utilisation of labour (Addison and Hirsch, 1997; Jolls, 2006; Trebilcock, 1993; Belot et al, 2007). Within both transaction cost economics and efficiency wage theory, for example, it is acknowledged that employment regulation can enable organisations to make more productive use of their resources (Addison et al.,1997; Erhel and Zajdela, 2004). For those working in the neoclassical paradigm, legal interventions can play a role in terms of supporting the achievement of -outcomes which competitive markets would not otherwise achieve. Trade-offs are, however, seen to exist between the costs and benefits of regulations aimed at the achievement of such outcomes (see e.g., Addison and Hirsch, 1997; Belot et al., 2007). It is consequently far from universally accepted that the presence of market failures provides a valid justification for regulatory labour market interventions (Coase, 1992) and hence 'market perfecting laws' (Deakin and Wilkinson, 2005: 282).

In summary the neo-classical view of EPL and the regulation of the labour market in general is that employment protection reduces productivity because it raises adjustment costs. Thus, by increasing the costs of dismissal, it leads to less firing and hiring being undertaken, with this causing less productive current workers being retained and potentially more productive new recruits not being hired. More detailed discussions and analysis of this relationship has been undertaken by Lazear (1990), Blanchard and Portugal (2001) and Autor et al (2007). The upshot of this is that neo-classical theorists will always oppose EPL in situations where it is likely to raise adjustment costs, but be more receptive to legislation that positively impacts upon market failure.

Institutionalist theoretical positions operating outside of the neo-classical paradigm, in contrast, offer more fundamental challenges to the view that employment laws constitute a 
harmful interference in the operation of labour markets (see e.g. Kaufman, 2009). They do so in two related ways. First, by viewing such laws as reflective of surrounding norms and other 'self-regulatory mechanisms', and hence to be 'mostly concerned with extending and standardising existing practices' (Deakin and Sarker, 2008: 461). Secondly, by arguing that their impact is to a large extent contingently shaped by the way in which they interact with other parts of a country's regulatory architecture, including such as those relating to corporate governance and product markets (see e.g. Amable et al, 2005; Brewster et al, 2006; Hall and Soskice, 2001; Whitley, 1999).

Such analyses therefore suggest that the conventional supply and demand model of the labour market may tend to overstate the extent to which the requirements of employment laws challenge existing market based practices. By highlighting how the operation of employment protection laws can be affected by surrounding institutional sub-systems, they also suggest that their outcomes are neither necessarily positive or negative, and that they may vary between different sectors and types of organisation (Bassanini and Venn, 2007), as well as across countries (see e.g. Amable et al., 2005; Gatti, 2008). Indeed, an important part of debates about the effects of employment regulation internationally has concerned whether it disproportionately impacts on small firms as a result of (a) the way in which employment laws often reflect the influence of 'good practice' in large firms and thereby requires much more adaption of practices within smaller ones (Edwards et al., 2004) and (b) their inability to obtain economies of scale in the administration of regulatory requirements. These arguments though, in turn, exist alongside evidence pointing to the fact that small firms are frequently unaware of their legal obligations and more often fail to comply with them (see e.g Kitching, 2006). 
Available empirical analyses within the fields of economics and social-legal studies reinforce such uncertainty concerning the economic impact of employment laws. Work within the latter field has, for example, highlighted how organisations vary considerably in the way in which they attitudinally approach legal compliance and respond to particular requirements. Thus, in the case of small firms it has been found that their responses can vary from non-compliance as a result of either ignorance or deliberate intent, full or partial compliance based on bearing the associated additional costs, and the pursuit of legal compliance but taking steps to recoup such costs through efficiency enhancing measures (Arrowsmith et al., 2003; Edwards et al., 2004; Edwards and Gillman, 1999; Marlow, 2002; Ram et al., 2001). In addition, it has been observed that differences in the way in which laws are enforced can significantly influence the impact that they have (Cazes et al., 2012).

As a result, there is commonly seen to exist trade-offs between the costs and benefits of regulation, and recognition that regulatory provisions can have beneficial effects in certain situations (see e.g. Belot et al., 2007). Indeed, in a rather perverse echo of public choice theory, it has been argued that business (and related political) resistance to costly regulatory measures, along with adjustments made by employer to offset regulatory costs, means that their economic impact will often be relatively muted (Addison and Hirsch, 1997: 9).

Furthermore, Addison and Hirsch (1997) have also highlighted the public good elements of working conditions and employment regulation, which is important since there is universal acceptance of state intervention in that sphere. As a result the debate is always likely to be about the point at which employment regulation becomes counterproductive rather than simply pressure from neo classical scholars to weaken or reduce the level of employment regulation. 
Economic based studies have similarly produced very mixed and contradictory findings regarding the impact of employment protection laws. ${ }^{3}$ For example, Bassanini and Venn (2007) in an analysis covering 18 OECD countries report a negative relationship between the strictness of such laws and labour productivity growth when 'EPL binding' industries, that is those with a high propensity to dismiss during economic downturns, are compared to nonbinding ones. In contrast, in a study involving 17 manufacturing sectors in the same number of OECD states, Scarpetta and Tressel (2004) did not find differences in labour market regulation to significantly affect multifactor productivity, while Storm and Naastepad (2007) in another study covering 20 OECD countries found aggregate labour productivity to be significantly higher in more regulated economies. ${ }^{4}$ Moreover, available findings provide a similarly mixed picture regarding how such laws affect the potentially productivity enhancing practices of technological innovation and investment (see e.g. Acharya et al., 2009; Bassanini and Ernst, 2002).

To confuse the situation further, there is evidence suggesting that a non-linear relationship exists between the strictness of employment protection laws, on the one hand, and private sector investment, on the other - evidence which therefore suggests that they have positive effects up to a certain level of strictness (Belot et al., 2007; Cazes et al., 2012). There are also findings which lend support to the institutionalist-based argument that the impact of employment laws is influenced by the way in which they interact with way in which employment laws interact with other regulatory sub-systems influences how far they haveadverse or positive effects (Amable, 2003; Hotho, 2014; Whitleely, 1999). 
Deakin and Sarker (2008) in a study exploring longitudinal links over the period 1970-2006 between movements in the level of labour regulation and productivity for four countries France, Germany, US and UK - report significant positive correlations in respect of the first two. In doing so, they argue that the findings concerned imply that labour regulations may have 'beneficial impacts when combined with other institutions in the context of co-ordinated market economies' (Deakin and Sarker, 2008: 478-479). Similarly, in their study Storm and Naastepad (2007) grouped the 20 countries studied into three groups, based on either the strictness of their employment protection index or a multivariate labour market regulation score and found productivity growth over the period 1984-97 to be highest in the 'Group 1' countries of Austria, Denmark, Finland, Germany, Japan, and Norway - that is in countries seen to be characterised by very strict employment protection, co-ordinated labour markets and relatively high real wage growth. ${ }^{5}$

These findings concerning the way in which different combinations of labour market features generate different economic outcomes in turn exist alongside findings pointing to the existence of systematic linkages between labour market institutions and other features of national institutional environments, including product market regulatory regimes, types of corporate governance, and patterns of ownership (see e.g. Amable et al., 2005; Conway et al., 2005; Deakin and Sarker, 2008; ). Thus, for example, a combination of high levels of employment protection and ownership concentration has been found to have a positive impact on productivity (Gatti, 2008). In short, considerable conceptual and empirical uncertainty surrounds the issue of whether, and to what extent, employment protection laws do in fact impact negatively on productivity. It is in this context that the analysis presented below has been undertaken with a view to shedding further light on it, while taking heed methodologically of the arguments of Freeman (2005) that (a) better evidence is needed of 
how labour laws operate at the firm and industry level and (b) that longitudinal evidence provides a more valid and stronger test of any claim regarding their impact.

To carry out the empirical analysis of the impact of employment protection legislation (EPL) on productivity we utilise a standard production function estimation framework which is commonly employed in productivity studies (e.g., Jorgenson et al., 1987; Forth and O’Mahony, 2003). The details of the production function specification leading to a labour productivity estimating equation are presented in the Appendix. There we define and discuss the standard control variables in the productivity growth specification, firm age and size, capital-labour ratio change, and the quality of labour force (cost of employees). In the next section we follow on from the preceding theoretical arguments and discuss the measurement issues related to the main variable of interest - the EPL, and also introduce the data used and our estimation strategy.

\section{Data and empirical method}

The empirical analysis which follows examines, as already mentioned, the links between employment protection and trends in labour productivity in four countries. More specifically, it does so by comparing the UK growth in productivity over the period 1999-2008 with that in three other countries, namely France, Germany and Sweden.

The relationship between employment regulation and aggregate productivity cannot be examined in isolation of national context, and industry and firm characteristics. Consequently, to achieve the aim of the study it was necessary to explore the relationship in the context of a wider analysis of the factors influencing productivity growth. For this reason the three comparator countries were chosen on the basis that (a) available indicators show them to be 
more highly regulated than the UK (Botera et al., 2004; Deakin and Sarkar, 2008; Venn, 2009; World Bank, 2008) and (b) they are seen within both the varieties of capitalism and national business systems literatures to exhibit marked institutional differences not only with the UK but themselves (see e.g. Esping-Andersen, 1994; Hall and Soskice, 2001; Whitley, 1999).

The available indicators of labour market regulation, as can be seen in Table 1, are relatively static and do not change substantially over the period of analysis; therefore they can be treated as essentially a fixed effect at country level. Furthermore, various indicators are only available for some sub-periods and for some countries in our analysis. Therefore, our first choice in the empirical analysis is to opt for country dummies to capture institutional and labour market regulation effects. This approach is widely used in related research contexts; for example, Calmfors and Driffill (1988) and a number of follow-up studies group countries according to their collective bargaining regimes for the purposes of their analysis and classify Sweden as a centralised economy, Germany as an intermediate one, and France and UK as decentralised economies.

Table 1 here

Relying only on country dummy variables is not completely satisfactory though as these might also capture other broader institutional effects. Therefore, we extend our analysis by creating an indicator variable (Factor), using OECD information on the strictness of employment protection and the trade union density (reported in sections A and D of Table 1) to develop a broader, institutionally based, indicator variable (Factor) of employment protection arrangements. ${ }^{6}$ We aggregate this information available through factor analysis by retaining a single factor, with eigenvalue above one. ${ }^{7}$ The average values of Factor for each of our four 
countries reported in Table 1 show a clear ranking in terms strictness of the degree of employment protection in line with the preceding discussion.

Such an analysis of the relationships between national employment regulation and productivity can potentially be undertaken in one of two main ways. The first is to conduct it at an aggregate level using macro data at the sector or economy level. The second, in contrast, entails initially analysing productivity at a firm level employing micro data and then aggregating firm level productivity measures to obtain economy-wide ones. Of these two approaches, the second has been accepted in recent literature as being the more appropriate and is therefore the one utilised here (e.g., Office for National Statistics, 2007). We apply it by measuring performance as labour productivity growth and specifying a productivity growth equation augmented with EPL measures and country controls capturing institutional and legal differences.

For the analysis we use the pan-European AMADEUS dataset of the Bureau van Dijk, which contains harmonised and comparable detailed financial statements records for representative samples of firms for all European countries. ${ }^{8}$ AMADEUS is a commercial dataset, widely available and used in numerous individual industry, country and cross-country studies. In the analysis we use three samples of representative manufacturing firms: a total sample where we aggregate over all firms in each 4-digit NACE industry; a sample of small firms where we aggregate only over firms with number of employees less than 50; and a sample of large firms where we aggregate only over firms with number of employees more than 150 . Each sample is created by aggregating firm data at 4-digit NACE industry level by selecting the representative (median) firm in each such industry sample. Thus the number of observations in the estimated samples is determined by the number of 'active' 4-digit NACE manufacturing industries in each country and year. Our estimated total sample contains 8,077 firm-year observations for 
the period 1999-2008; the number of observations in the small and large firm estimated samples are 6,628 and 7,776 respectively. The three samples should be seen as alternative representations of the firm data.

To facilitate testing for the impact of employment protection on productivity while controlling for the impacts of the technology and capital and labour inputs, we employ a cross-country panel regression framework.

Our estimating equation, in its dynamic specification, equation (4) in the Appendix, has labour productivity as its dependent variable, which is a function of the one-period lagged labour productivity, capital-labour ratio change and a vector of control variables capturing effects of total factor productivity (TFP) determinants such as firm and industry characteristics as well as the country's institutional and regulatory environment. Candidates for control variables, besides the standard age and size of the firm, include work force skill levels (measured as cost per employee), institutional measures (country dummies and/or indicators for employment protection), industry effects (2-digit NACE) and time dummies to capture business cycle effects. Summary statistics and definition of all the regression variables are reported in Table 2. The impact of these variables is discussed in the next section in the context of the panel regression results as in the focus of the discussion are the employment protection effects.

Table 2 here

A dynamic panel generalized method of moments (GMM) estimator following Arellano and Bond (1991) and its extension to system GMM by Blundell and Bond (1998) is used to 
estimate the labour productivity equation over the ten-year period. The estimator controls for unobserved firm (industry) heterogeneity and allows for a consistent estimation of the lagged dependent variable's coefficient. In the econometric analysis we treat the explanatory variables as predetermined except for the country, industry and time controls which we treat as exogenous. ${ }^{9}$

The estimation is complicated because of the nature of the main explanatory variable of interest in our analysis - the employment protection indicator, Factor - that has little withincountry variance and shows much more variation across countries than over time.

Furthermore, Factor is strongly determined by the country institutions, and thus the country fixed effects in the regressions. This aggravates the inefficiency of estimation and may lead to unreliable point estimates that would then lead to incorrect inferences in the same way that a biased estimator could. Consequently, besides the specification with country fixed effects we also estimate a specification with only the employment protection indicator, Factor as well as a specification with Factor, country fixed effects and interaction terms.

As an additional robustness check, following ideas in Plümper and Troeger (2007) and Minns and Rizov (2015), we estimate a specification where we replace Factor with the residuals estimated from an auxiliary regression that decomposes the employment protection indicator (Factor) total effects into a fixed (country) effect and a time-varying (unexplained) idiosyncratic effect, captured by the residuals. Results from the auxiliary regressions are reported in the Appendix, Table A1 and demonstrate the strong explanatory power of the country (institutional) fixed effects. It is not unreasonable to perform an orthogonal decomposition into explained and unexplained parts as described above. Clearly, the orthogonality assumption may often be incorrect and this would inevitably bias the estimated 
coefficients of the fixed effect variables. However, we are only interested in the estimated residuals and in any case the potential bias in the coefficients under regularity conditions does not affect the estimation precision of the second stage (Plümper and Troeger 2007).

\section{Data Analysis}

In the data analysis we estimate specifications based on equation (4) from the Appendix and report results in Tables 3a, 3b, 3c and 3d. The model is estimated for all firms and then separately for large and small firm samples, since the expectation is that smaller firms will benefit most from a more flexible employment regulation (less employment protection) regime (see e.g. Addison and Hirsch, 1997: 79). In all specifications the tests for (second order) autocorrelation and exogeneity of the instruments are satisfied.

In terms of the explanatory variables most of the a priori expectations are confirmed for all specifications as the magnitude and sign of the effects remain consistent.

Table 3a here

In Table 3a, presenting our base specification with country dummy variables capturing the impact of employment protection, the lagged dependent variable is positive and significant suggesting that previous period labour productivity is a good predictor of current labour productivity, therefore those firms displaying better productivity in the past are more likely to also show that in subsequent periods. This is most evident in the case of large firms, and to a degree for the full sample, while labour productivity growth occurs on a more random basis within the small firm sample. An increase in the capital-labour ratio has a positive and 
significant impact upon labour productivity supporting the view that where labour has more capital to work with it is likely to be more productive. Overall firm's age appears to be irrelevant as determinant of labour productivity. However, when analysed separately by firm size samples, it is clear that this masks two opposing effects. Firstly, amongst large firms, it is the eldest firms and industries that have the lowest labour productivity growth, reflecting the likelihood that as older industries reach maturity the scope for productivity growth in general and labour productivity growth in particular is much lower. Secondly, amongst the small firms, it is the older ones who experienced the strongest growth in labour productivity, suggesting that amongst these firms it is the most well established ones in each industry who are best placed to take advantage of developments in production techniques and market conditions. Sales turnover, as a proxy for firm size, has a positive and significant impact upon the rate of growth of labour productivity. However, once again the extent of the impact is diluted as there are different effects at work within firm size samples. Amongst the large firms it is the largest ones that exhibit the highest labour productivity, whilst within the small firm sample, size does not affect productivity. The cost per employee has a strong positive correlation with labour productivity. As this is a proxy for skill levels of the workforce, it indicates that where the firm pays higher wages and employs workers with higher levels of skill the scope for growth in labour productivity is greater. Over the period of analysis there was initially a reduction in labour productivity which was then followed by strong growth for the remaining six years, with this being more pronounced amongst the small firms.

Turning to the impact of individual countries, relative to France, the UK and especially Germany have displayed stronger growth in labour productivity over the period consideredW. The labour productivity growth in Sweden has been the weakest being significantly lower than the French reference category. For Germany, the stronger productivity growth was 
entirely the result of increases in labour productivity within the large firms; growth within the small firms sample being not significantly different from that experienced by those in Sweden and France. However for the UK the picture is reversed with the strong labour productivity growth resulting entirely from improvements within the small firm sample, which have been significantly greater than within the small firms of any of the other three countries. The position for the UK, whilst not being a ringing endorsement for the application of light touch employment regulation, does at least therefore concur with the hypothesis that it is the smaller firms that are most likely to benefit from lighter employment regulation as larger firms are always able to use more resources as a means to navigate their path through complex regulations.

Table $3 b$ here

In the above discussion we interpret the country effects as capturing the impact of employment protection on labour productivity. This choice is motivated by the fact that the indicator of employment protection available is relatively static and does not change substantially over the period of analysis; furthermore the results from estimating the impact of country dummies on the employment protection indicator (Factor) reported in Table A1 in the Appendix confirm the strong relationship between the country effects and the employment protection. Nevertheless, country dummies may confine employment protection effects with other institutional influences. Therefore, as discussed in the previous section, we estimate three more specifications where we try to disentangle the effect of employment protection on labour productivity. In Table $3 \mathrm{~b}$ we report results from specification without country dummies with only the indicator of employment protection, Factor included. The coefficients of the control variables remain similar to the one reported in Table $3 \mathrm{a}$. The 
interesting finding is that employment protection has, in general, a positive effect on productivity as the impact is stronger in the sample of large firms; this is consistent with our expectations.

Tables $3 \mathrm{c}$ and $3 \mathrm{~d}$ here

Next we estimate two more specifications where the country dummies and the employment indicator as well as their interaction effects are all included. From the previous analysis it became clear that our employment protection indicator is highly correlated with the country effects. Therefore in the GMM estimation we treat Factor as endogenous and use long lags as instruments. In Table 3c the results from the specification with country dummies, Factor, and interaction terms appear broadly consistent with previous specification results; the total country effects, comprising the sum of three components (country, Factor, and interaction terms) for each country we preserve the country ordering found from the results in Table $3 \mathrm{a}$. Nevertheless, we do not consider the estimated coefficient magnitudes reliable, because of the severe collinearity problem with the employment protection indicator causing the fixed effects to soak most of the variation, and further estimate a specification where we replace Factor with its residual (ResFactor) from the orthogonal decomposition regression, results from which are reported in Table A $1 .{ }^{10}$ As discussed earlier such specification avoids the endogeneity and collinearity problems associated with estimating the effects of slowly changing (institutional) variables, such as the employment protection indicator. The results reported in Table $3 \mathrm{~d}$ are in line with results from previous specifications, specifically the total country effects are similar to the results reported in Table $3 \mathrm{a}$, and can be taken as robustness test of the impact of employment protection on labour productivity. 


\section{Discussion}

In drawing the paper to a conclusion, the results obtained in respect of the UK and Germany are initially discussed, followed by those from France and Sweden combined. In each case the discussion is used to draw out the theoretical implications of the findings concerned. Finally, the ramifications of these for future research and policy are considered.

The UK had the second best rate of productivity growth as a result of the improvements achieved within its small firm sample. Considered in isolation, its results could consequently be taken to support the virtues of a relatively limited approach to employment protection regulation and to add weight to the argument that such an approach is likely to be particularly beneficial to small firms (Addison and Hirsh, 1997: 9). This apparent endorsement of 'light touch' regulation, however, is challenged by the finding that productivity growth was highest for the more highly regulated Germany. At the same time, the fact that this overall performance was driven by larger firms lends further support to the view that such firms are better placed to accommodate the demands of employment legislation.

The relatively poorer productivity performances of France and Sweden meanwhile serve to confuse the situation further. According to the OECD employment protection index, these two countries are more highly regulated than the UK but sit either side of Germany. Their performances would consequently seem inconsistent with the argument that there is a straightforward negative or positive relationship between levels of employment protection, on the one hand, and trends in productivity growth, on the other; or for that matter the suggestion that such a positive relationship exists up to a certain level of regulatory protection (Belot et al., 2007; Cazes et al., 2012). Instead, they logically lend force to the argument that the 
impact of employment protection on productivity varies contingently, both within and across countries.

More specifically, the pattern of findings obtained add weight to the type of institutionalistbased arguments outlined earlier (see Amable 2003; Hall and Soskice, 2001; Whitley, 1999) as well as being potentially compatible with findings which suggest that employment laws impact differentially on different sizes of firms and industries (see e.g. Belot et al., 2007: 383). At the same time, this is not to discount the potential explanatory role of such perspectives on the role of employment laws as those offered by transaction cost and wage equity theories. For these potentially provide frameworks for understanding how such sources of structural influence actually impact on employer and worker behaviour, and hence productivity.

Indeed, the recent study by Frege and Godard (2014) serves to highlight the need to pay attention to the role of mediating processes in influencing the impact of surrounding institutional features. Thus, in exploring the differing job quality implications of the very different employment systems in Germany and the United States, they draw attention to the way in which the nature, functioning and legitimacy of institutional structures are shaped by supporting logics and norms. In addition, they present findings pointing to how worker experiences of national employment systems can be mediated by employer 'workplace regimes' and their own subjective expectations.

It would therefore appear important-,_in seeking to improve our understanding of how employment laws in general, and employment protection ones in particular, influence economic outcomes,-for future research $h_{-}, \underline{I}_{-}$in the words of Frege and Godard (2014: 960), to go 'beyond assumed systems effects to address the specific mechanisms by which these environments do (or do not) matter' ${ }^{11}$ Certainly, on the basis of the findings obtained, we 
need to more fully understand the dynamics through which such laws influence the behaviours of employers and workers and the way in which these shape the economic outcomes associated with them.

\section{Conclusion}

This paper set out to explore the validity of the alleged economic virtues of pursuing a comparatively limited approach towards the regulation of employment protection. It did so by comparing the UK's manufacturing productivity performance with those of three countries France, Germany and Sweden - that possess more stringent employment protection laws.

Overall, the empirical findings obtained failed to support the existence of a clear negative relationship between legal stringency and productivity. While the UK was found to have experienced relatively good productivity growth, its performance in this regard was below that of the more highly regulated Germany. On the basis of the empirical findings obtained, it has therefore been concluded that it is theoretically difficult to support the existence of a generally applicable negative linear relationship between regulatory stringency and productivity growth. Rather, the impact of employment laws is better seen to be the product of complex, contextually shaped processes that act to differentially influence how particular provisions affect employers both within and across national settings. Insofar as this is correct, it is argued that policymakers should move beyond simplistic neo-classical type assumptions concerning the economic consequences of employment regulations. More specifically, the findings suggest that the terms of the policy debate should shift from a concentration on 'less regulation versus more regulation' to a focus on the way in which regulations and associated institutions can be best designed to support the achievement of desired outcomes - be these of an economic or, as in the case of objectives relating to the achievement of greater equity, fairness and justice, non-economic nature (Cazes et al., 2012: 36). 
There would consequently seem to be a need for much more in-depth knowledge -of how particular laws operate in particular organisational, sectoral and national settings. For the authors, such knowledge is most likely to emerge from micro-level studies that enable the operation of employment laws to be dynamically examined within their surrounding institutional and market contexts. While some studies of this type already exist (see e.g. Caroli et al., 2010; Martinez Lucio et al., 2001), more would seem needed if we are to obtain rich and sound understandings of the day-to-day effects of employment laws and the policy issues arising from them.

\section{Appendix}

\section{Estimation framework}

To understand better the channels through which employment regulations may affect labour productivity we formulate a simple production function model where the level of output (real value added, $V$ ) of firm (industry) $j$ at time $t$ is expressed as a function of aggregate capital inputs $(K)$, aggregate labour inputs $(L)$ and the production technology shifter $(A)$ :

$V_{j t}=A_{j t} f\left(K_{j t}, L_{j t}\right)$

The values of capital and labour inputs capture both quantity and quality. The production technology refers to the rate at which units of capital and labour are converted into output and is often referred to as total factor productivity (TFP).

The growth in firm $j$ output over the period ( $t-1$ to $t$ ) is determined by changes in labour inputs, changes in capital inputs and changes in TFP. ${ }^{12}$ The most commonly employed 
formalisation of such relationships is based on the assumption of a Translog production function and obtained via the Törnqvist discrete approximation to the Divisia index (e.g., Jorgenson et al., 1987). If with $\mathrm{d} X_{j t}$ we denote the proportionate change in a variable $X_{j t}$ (standing for $V, L, K$, or $A$ ) between period $t-1$ and $t$, i.e. $\mathrm{d} X_{j t}=\ln \left(X_{j t} / X_{j t-1}\right)$, and impose constant returns to scale then the Törnqvist index is given by:

$\mathrm{d} V_{j t}=a_{j t} \mathrm{~d} L_{j t}+\left(1-a_{j t}\right) \mathrm{d} K_{j t}+\mathrm{d} A_{j t}$,

where $a_{j t}$ is the share of labour in value-added, averaged over the two time periods. Under neo-classical assumptions, the shares of labour and capital, $a_{j t}$ and $\left(1-a_{j t}\right)$ equal the output elasticity of labour and capital respectively and since we imposed constant returns to scale, sum to one. The rate of change in $A_{j t}(\mathrm{TFP})$ is a catch-all for technological or organizational improvements, such as process innovations and changes in work organization, that increase the level of output for a given amount of input. Changes in the quality of factor inputs, e.g., a greater use of new technology equipment or highly skilled labour, may be incorporated within this framework by weighting each of a number of types of capital or labour by their value added shares (e.g., Jorgenson et al., 1987). If this adjustment for quality is not carried out directly then the TFP term also incorporates the impact of input quality changes.

This method of accounting for growth in output can be easily extended to permit a focus on changes in labour productivity (e.g., Forth and O’Mahony, 2003). Having identified the impact of changes in the quantityof labour input (for example, the number of employees), we can subtract this from the changes in output in Equation (2), and using the fact that the input weights sum to one, derive a labour productivity equation of the form: 
$\mathrm{d}\left(V_{j t} / L_{j t}\right)=\left(1-a_{j t}\right) \mathrm{d}\left(K_{j t} / L_{j t}\right)+\mathrm{d} A_{j t}$

Thus changes in labour productivity $\left(V_{j t} / L_{j t}\right)$ depend on changes in the capital-labour ratio $\left(K_{j t} / L_{j t}\right)$ or capital deepening and TFP. ${ }^{13}$ This equation provides a framework for better understanding the sources of labour productivity changes given employment regulation.

Next, we transform the first-differenced equation (3) into a dynamic specification which provides our estimating equation:

$V_{\mathrm{j} t} / L_{\mathrm{jt}}=\alpha+\beta V_{j t-1} / L_{j t-1}+\gamma d\left(K_{j t} / L_{j t}\right)+\sum_{s} \delta_{s} Z_{j t}+\varepsilon_{j t}$,

where $Z_{j t}$ is a vector of $s$ control variables capturing effects of TFP determined by firm and industry characteristics as well as by the country's institutional and regulatory environment. 
Table A1: Decomposition of Factor, country level regressions

\begin{tabular}{|c|c|c|c|c|}
\hline Variable & Coeff. & t-value & R-sq. & No obs. \\
\hline Germany & 0.586 & 14.83 & 0.99 & 40 \\
\hline UK & -1.964 & 55.04 & & \\
\hline Sweden & 0.154 & 4.00 & & \\
\hline Year controls & Yes & & & \\
\hline
\end{tabular}




\section{References}

Acharya VV, Baghai-QWadji R and Susbramanian K (2009) Labor Laws and Innovation. Discussion Paper No. 7171. London: CEPR.

Addison JT and Hirsch BT (1997) The economic effects of employment regulation: What are the limits? In: Kaufman BE (ed) Government Regulation of the Employment Relationship. Madison, WI: Industrial Relations Research Association, pp.125-178.

Addison JT, Barrett CR and Siebert, WS (1997) The economics of labour market regulation. In: Addison JT and Siebert WS (eds) Labour markets in Europe: Issues of Harmonization and Regulation. Dryden Press, pp.62-104.

Amable B (2003) The Diversity of Modern Capitalism. Oxford: Oxford University Press.

Amable B, Ernst E and Palombarini S (2005) How do financial markets affect industrial relations? An institutional complementarity approach, Social-Economic Review 3(2): 311330.

Arellano M, and Bond S (1991) Some tests of specification for panel data: Monte Carlo evidence and an application to employment equations. Review of Economic Studies 58(2): 277-197.

Armingeon K and Baccaro L (2012) Political economy of the sovereign debt crises: The limits of internal devaluation. Industrial Law Journal 41(3): 254-275.

Arrowsmith J, Gilman MW, Edwards P and Ram M (2003) The impact of National Minimum wages in small firms. British Journal of Industrial Relations 41(3): 435-456.

Autor, D., Kerr, W. and Kugler, A. (2007) Does Employment Protection Reduce Productivity? Evidence From US States. The Economic Journal 117 (52): F189-F217.

Ball, S (2001)The European Employment Strategy: The will but not the way? Industrial Law Journal 30(4): 353-374.

Barnard, C (2012) The Financial Crises and the Euro Plus Pact: A labour lawyer's perspective. Industrial Law Journal 41(1): 98-114.

Bassanini A and Ernst E (2002) Labour market regulation, industrial relations and technological regimes. Industrial and Corporate Change 11(3): 391-426.

Bassanini A and Venn D (2007) Assessing the Impact of Labour Market Policies on Productivity: A Differences - in - Differences Approach. OECD Social, Employment and Migration Working Paper. No.35. Paris: OECD.

Belot M, Boone J and van Ours J (2007) Welfare-improving employment protection. Economica 74(295): 381-396.

Blanchard, O. and Portugal, P. (2001). What hides behind an unemployment rate: comparing Portuguese and US labor markets, American Economic Review, vol. 91(1), pp. 187-207. 
Blundell R and Bond S (1998) Initial conditions and moment restrictions in dynamic panel data models. Journal of Econometrics 87(1): 115-143.

Botero JC, Djankov S, La Porta R, Lopez-De-Silanes F and Shleifer A (2004) The regulation of labor. The Quarterly Journal of Economics 119(4): 1339-1382.

Brewster C, Wood G and Brookes M (2006) Varieties of capitalism and varieties of firms. In: Wood G and James P (eds) Institutions, Production and Working Life. Oxford : Oxford University Press, pp.217-234.

Busby, N, McDermont, M, Rose, S and Sales, A (2013) Access to Justice in Employment Disputes: Surveying the Terrain. Liverpool: Institute of Employment Rights.

Calmfors, L. and Driffill, J (1988) Bargaining structure, corporatism and macroeconomic performance. Economic Policy, April, pp. 14-61.

Caroli E, Gautie, J, Lloyd, C, Lamanthe, A and James, S (2010). Delivering flexibility: Contrasting patterns in the French and the UK food processing industry. British Journal of Industrial Relations 48(2): 284-309.

Casey, B (2004) The OECD Jobs Strategy and the European Employment Strategy: Two views of the labour market and the welfare state. European Journal of Industrial Relations 10(3): 329-352.

Cazes S, Khatiwada S and Malo M (2012) Employment Protection and Collective Bargaining: Beyond the Deregulation Agenda. Geneva: International Labour Organization.

Coase R (1988) The Firm, the Market and the Law. Chicago: University of Chicago Press.

Coase R (1992) The institutional structure of production. American Economic Review. 82: 713-719.

Conway P, Janod V and Nicoletti G (2005) Product Market Regulation in OECD Counties: 1998-2003. Geneva: OECD.

Davies, P and Freedland M (2007) Towards a Flexible Labour Market : Labour Legislation and Regulation since the 1970s. Oxford: Oxford University Press.

Deakin S and Sarkar P (2008) Assessing the long-run economic impact of labour law systems: A theoretical reappraisal and analysis of a new time series. Industrial Relations Journal 39(6): 453-487.

Deakin S and Wilkinson F (2005) The Law of the Labour Market: Industrialization, Employment and Legal Evolution. Oxford: Oxford University Press.

Department for Business Enterprise and Regulatory Reform (2008) Impact of Regulation on Productivity. London: BERR. 
Department for Business Innovation and Skills (2011) Flexible, Effective, Fair: Promoting Economic Growth through a Strong and Efficient Labour Market. London: BIS.

Dickens L and Hall M (2003) Labour law, industrial relations: A new settlement? In Edwards P (ed) Industrial Relations: Theory and Practice. $2^{\text {nd }}$ Edtn. Oxford: Blackwell, pp.124-158.

Edwards P and Gilman M (1999) Pay equity and the National Minimum Wage, Human Resource Management Journal, 9(1): 20-38.

Edwards P, Ram M and Black J (2004). Why does employment legislation not damage small firms? Journal of Law and Society 31(2): 245-265.

Epstein R (1984) In defense of the contract at will. University of Chicago Law Review 51(4): 947-82.

Erhel C and Zajdela, H (2004) The dynamics of social and labour market policies in France and the United Kingdom: Between path dependence and convergence. Journal of European Social Policy 14(2): 125-142.

Esping-Andersen, G (1994) The Three Worlds of Welfare Capitalism. Cambridge: Polity Press European Commission (2007) Towards Common Principles of Flexicurity: More and Better Jobs through Flexibility and Security. Luxembourg: Office for Official Publications.

European Commission (2009) The Employment Crises, Trends, Policy Responses and Key Actions: European Commission Background Paper to the EPSCO Council. Brussels:

European Commission.

Ewing K and Hendy J (2012) Unfair dismissal changes - unfair? Industrial Law Journal 41(1): 115-121.

Forth J and O'Mahony M (2003) The Impact of the National Minimum Wage on Labour Productivity and Unit Labour Costs. London: National Institute of Economic and Social Research, (Available at www.lowpay.gov.uk/lowpay/research/pdf/forth.pdf<http://www.lowpay.gov.uk/lowpay/resear ch/pdf/forth.pdf ).

Freeman R (2005) Labour market institutions without blinders: The debate over flexibility and labour market performance. NBER Working Paper No. 11286.

Frege C and Godard J (2014) Varieties of capitalism and job quality: The attainment of civic principles at work in the United States and Germany. American Sociological Review 79(5): 942-965.

Gatti D (2008) Macroeconomic Effects of Ownership Structure in OECD Countries. IZA Discussion Paper No. 3415. Bonn: IZA.

Goetschy, J (1999) The European Employment Strategy: Genesis and development. European Journal of Industrial Relations. 5(2): 117-137. 
Hall P and Soskice D (eds) (2001) Varieties of Capitalism: The Institutional Basis of Competitive Advantage. Oxford: Oxford University Press.

Hepple B (2013) Back to the future: Employment Law under the Coalition government. Industrial Law Journal 42(3): 203-223.

Heyes, J (2011) Flexicurity, employment protection and the job crises. Work, Employment and Society 25(4): 642-657.

Heyes, J (2013) Flexicurity in crises: European labour market policies in a time of austerity. European Journal of Industrial Relations 19(1): 71-86.

Hotho J (2014) From typology to taxonomy: A configurational analysis of National Business Systems and their explanatory power. Organization Studies 35(5): 671-702.International Labour Organization (2012) World of Work Report: Better Jobs for a Better Economy. Geneva: International Labour Office.

Jolls C (2006) Law and the labor market. Annual Review of Law \& Social Science 2: 359-85.

Jorgenson D, Gallup F and Fraumeni B (1987) Productivity and US Economic Growth. Cambridge, MA: Harvard University Press.

Kaufman BE (2009) Labor law and employment regulation: Neoclassical and institutional perspectives. In Dau-Schmidt K, Harris, S and Lobel O (eds) Labor and Employment Law and Economics. Massachusetts: Edward Elgar, pp. 3-59.

Kitching J (2006) A burden on business? Reviewing the evidence base on regulation and small business performance. Environment and Planning C: Government and Policy 24(2): 799-814.

Lazear, E. (1990). Job security provisions and employment, Quarterly Journal of Economics, vol. 105(3), (August), pp. 699-726.

Marlow S (2002) Regulating labour management in small firms, Human Resource Management Journal 12(3): 25-43.

Martinez Lucio M, Turnbull, P, Blyton, P and McGurk, J (2001) Using regulation: An international comparative study of the civil aviation industry in Britain and Spain. European Journal of Industrial Relations 7(1): 49-70.

Meardi, G (2011) Flexicurity meets state traditions. International Journal of Comparative Labour Law and Industrial Relations 27(3): 255-270.

Minns, C. and Rizov, M. (2015) Institutions, history and wage bargaining outcomes: International evidence from the post-World War Two era. Business History, forthcoming.

ONS (Office for National Statistics) (2007) The ONS Productivity Handbook, Palgrave MacMillan, Basingstoke. 
Organization for Economic Cooperation and Development (1994) Jobs Strategy: Facts, Analysis, Stategies. Paris: OECD

Organization for Economic Cooperation and Development (2006) Boosting Jobs and Income: Policy Lessons from Reassessing the OECD Jobs Strategy. Paris: Organization for Economic Cooperation and Development (2006b) OECD Employment Outlook: Boosting Jobs and Incomes. Paris: OECD

Plümper, T. and Troeger V.E. (2007) Efficent Estimation of Time-Invariant and rarely Changing Variables in finite Sample Panel Analyses with Unit Fixed Effects. Political Analysis 15(2): 124-139.

Ram M, Edwards P, Gilman M and Arrowsmith J (2001) The dynamics of informality: Employment relations in small firms and the effects of regulatory change. Work, Employment and Society 15(4): 845-861.

Reed H (2010) Flexible with the Truth? Exploring the Relationship between Labour Market Flexibility and Labour Market Performance. London: Trades Union Congess.

Scarpetta S and Tressel T (2004) Boosting Productivity Via Innovation and Adoption of New Technologies: Any Role for Labour Market Institutions? World Bank Research Working Paper 3273. Washington, DC: World Bank.

Storm S and Naastepad C (2007) Why Labour Market Regulation May Pay Off: Worker Motivation, Co-ordination and Productivity Growth. Geneva: International Labour Organization.

Sugden R (1989) Spontaneous Order. In: P Newman (ed) The New Palgrave Dictionary of Economics and Law: Vol 3. London: Macmillan, pp. 485-495.

Traxler F and Kittel B (2000) The bargaining system and performance: A comparison of OECD countries. Comparative Political Studies 33(9) 1154-1189.

Trebilcock M (1993) The Limits of Freedom of Contract. Cambridge: Harvard University Press.

Van Biesebroeck J (2008) The sensitivity of productivity estimates: Revisiting three important debates. Journal of Business and Economic Statistics 26(3): 311-328.

Venn D (2009) Legislation, Collective Bargaining and Enforcement: Updating the OECD Employment Protection Indicators. OECD Social, Employment and Migration Working Paper.No. 89. Paris: OECD.

Whitley R (1999) Divergent Capitalisms: The Social Structuring and Change of Business Systems. Oxford: Oxford University Press.

World Bank (2008) Doing Business 2008: Comparing Regulation in 178 Economies. Washington DC: International Bank for Reconstruction and Development. 
Table 1: Labour market regulation indicators

\begin{tabular}{|c|c|c|c|c|}
\hline Indicators & $\begin{array}{c}\text { France } \\
\text { Mean } \\
\text { (Change) }\end{array}$ & $\begin{array}{c}\text { Germany } \\
\text { Mean } \\
\text { (Change) }\end{array}$ & $\begin{array}{c}\text { Sweden } \\
\text { Mean } \\
\text { (Change) }\end{array}$ & $\begin{array}{c}\text { UK } \\
\text { Mean } \\
\text { (Change) }\end{array}$ \\
\hline \multicolumn{5}{|l|}{$\begin{array}{l}\text { A. OECD strictness of employment } \\
\text { protection index (1999-2008) }\end{array}$} \\
\hline $\begin{array}{l}\text { Individual and collective dismissals } \\
\text { (regular contracts) } \\
\text { Collective dismissals (additional } \\
\text { provisions) } \\
\text { Temporary employment }\end{array}$ & $\begin{array}{c}2.69 \\
(+0.09) \\
3.38 \\
(0.00) \\
3.62 \\
(0.00) \\
\end{array}$ & $\begin{array}{c}3.04 \\
(+0.13) \\
3.62 \\
(0.00) \\
1.33 \\
(-0.10) \\
\end{array}$ & $\begin{array}{c}2.59 \\
(-0.03) \\
2.88 \\
(0.00) \\
1.38 \\
(-0.63) \\
\end{array}$ & $\begin{array}{c}1.66 \\
(+0.12) \\
2.50 \\
(0.00) \\
0.32 \\
(+0.12) \\
\end{array}$ \\
\hline \multicolumn{5}{|l|}{$\begin{array}{l}\text { B. Deakin et al. (2007) CBR labour } \\
\text { regulation index (1999-2005) }\end{array}$} \\
\hline Alternative employment contracts & $\begin{array}{c}0.93 \\
(0.00)\end{array}$ & $\begin{array}{c}0.76 \\
(+0.07)\end{array}$ & - & $\begin{array}{c}0.47 \\
(0.24)\end{array}$ \\
\hline Regulation of working time & $\begin{array}{c}0.76 \\
(0.00)\end{array}$ & $\begin{array}{c}0.60 \\
(0.00)\end{array}$ & - & $\begin{array}{c}0.18 \\
(0.00)\end{array}$ \\
\hline Regulation of dismissal & $\begin{array}{c}0.74 \\
(0.00)\end{array}$ & $\begin{array}{c}0.50 \\
(+0.09)\end{array}$ & - & $\begin{array}{c}0.43 \\
(-0.03)\end{array}$ \\
\hline Employee representation & $\begin{array}{c}0.61 \\
(0.00)\end{array}$ & $\begin{array}{c}0.68 \\
(0.00)\end{array}$ & - & $\begin{array}{c}0.27 \\
(+0.17)\end{array}$ \\
\hline Industrial action & $\begin{array}{c}0.83 \\
(0.00)\end{array}$ & $\begin{array}{c}0.40 \\
(0.00)\end{array}$ & - & $\begin{array}{c}0.31 \\
(+0.11)\end{array}$ \\
\hline \multicolumn{5}{|l|}{$\begin{array}{l}\text { C. Public expenditure on labour market } \\
\text { policies as \% of GDP (2004-2008) }\end{array}$} \\
\hline Active measures & $\begin{array}{c}0.91 \\
(-0.11)\end{array}$ & $\begin{array}{c}0.89 \\
(-0.28)\end{array}$ & $\begin{array}{c}0.87 \\
(-0.24)\end{array}$ & $\begin{array}{c}0.37 \\
(-0.14)\end{array}$ \\
\hline Passive measures & $\begin{array}{c}1.42 \\
(-0.53)\end{array}$ & $\begin{array}{c}1.70 \\
(-1.22)\end{array}$ & $\begin{array}{c}1.01 \\
(-0.81)\end{array}$ & $\begin{array}{c}0.18 \\
(+0.02)\end{array}$ \\
\hline \multicolumn{5}{|l|}{$\begin{array}{l}\text { D. Other labour market institutions } \\
(1999-2008)\end{array}$} \\
\hline Trade union density & $\begin{array}{c}7.80 \\
(-0.40)\end{array}$ & $\begin{array}{c}22.04 \\
(-5.50)\end{array}$ & $\begin{array}{c}75.28 \\
(-10.80)\end{array}$ & $\begin{array}{c}28.84 \\
(-3.10)\end{array}$ \\
\hline $\begin{array}{l}\text { Minimum wage relative to average } \\
\text { wage }\end{array}$ & $\begin{array}{c}0.48 \\
(+0.05)\end{array}$ & - & - & $\begin{array}{c}0.36 \\
(+0.04)\end{array}$ \\
\hline $\begin{array}{l}\text { E. Factor (employment protection } \\
\text { indicator) }\end{array}$ & $\begin{array}{c}0.41 \\
(+0.02) \\
\end{array}$ & $\begin{array}{c}0.89 \\
(+0.03) \\
\end{array}$ & $\begin{array}{c}0.42 \\
(-0.01) \\
\end{array}$ & $\begin{array}{c}-1.65 \\
(+0.03) \\
\end{array}$ \\
\hline
\end{tabular}

Note: Source for sections A, C and D is OECD; source for section B is Deakin et al. (2007). The indicator variable, Factor in section $\mathrm{E}$ is generated by factor analysis using available information from sections A and D (trade union density). 
Table 2: Definitions of regression variables and summary statistics

\begin{tabular}{clccc}
\hline Variable & Definition & \multicolumn{3}{c}{ Mean (S.D.) } \\
\cline { 3 - 4 } & & Small firms & Large firms & All firms \\
\hline V/L & Labour productivity in & 53.122 & 56.921 & 55.578 \\
& thousands of real Euros & $(31.275)$ & $(29.695)$ & $(35.762)$ \\
V/L growth & Labour productivity growth & 0.009 & 0.013 & 0.011 \\
& & $(0.249)$ & $(0.241)$ & $(0.397)$ \\
K/L & Capital/labour ratio in thousands & 27.019 & 29.553 & 27.202 \\
& of real Euros & $(41.331)$ & $(37.055)$ & $(64.245)$ \\
K/L change & Change in capital/labour ration & -0.064 & -0.045 & -0.063 \\
& & $(0.459)$ & $(0.450)$ & $(0.766)$ \\
Firm age & Firm age & 21.352 & 28.348 & 21.493 \\
& & $(10.011)$ & $(17.810)$ & $(19.542)$ \\
Sales & Total sales in thousands of real & 11154.890 & 25349.680 & 12937.680 \\
& Euros & $(76719.850)$ & $(235696.300)$ & $(86365.210)$ \\
Fixed assets & Total fixed assets in thousands & 2601.937 & 4781.782 & 3567.632 \\
& of real Euros & $(34133.110)$ & $(85602.380)$ & $(43553.800)$ \\
L & Number of full-time equivalent & 40.013 & 285.892 & 93.320 \\
& employees & $(324.986)$ & $(2962.870)$ & $(688.688)$ \\
C/E & Cost per employee in thousands & 49.784 & 62.240 & 55.423 \\
& of real Euros & $(2.042)$ & $(3.290)$ & $(2.948)$ \\
V & Value added in thousands of real & 4520.471 & 14680.320 & 8905.856 \\
& Euros & $(28469.440)$ & $(109022.000)$ & $(69788.320)$ \\
Factor & Employment & 0.0 & 0.0 & 0.0 \\
& indicator (standardised) & $(0.999)$ & $(0.998)$ & $(0.998)$ \\
\hline No. observations & 6628 & 7776 & 8077 \\
\hline Note: The & & &
\end{tabular}

Note: The real monetary values are calculated by deflating with 4-digit NACE producer price index (PPI) with 2000 as a base year. 
Table 3a: Empirical models of labour productivity growth

\begin{tabular}{|c|c|c|c|c|c|c|}
\hline \multirow{2}{*}{ Variable } & \multicolumn{2}{|c|}{ Small firms } & \multicolumn{2}{|c|}{ Large firms } & \multicolumn{2}{|c|}{ All firms } \\
\hline & Coeff. & Z-score & Coeff. & Z-score & Coeff. & Z-score \\
\hline Lagged Log V/L & -0.024 & 0.86 & 0.371 & 10.12 & 0.060 & 2.14 \\
\hline $\mathrm{K} / \mathrm{L}$ change & 0.016 & 3.03 & 0.037 & 6.28 & 0.011 & 2.10 \\
\hline Log Firm age & 0.038 & 3.53 & -0.091 & 4.16 & 0.013 & 0.91 \\
\hline Log Sales & 0.019 & 1.02 & 0.111 & 7.15 & 0.037 & 2.90 \\
\hline $\log C / E$ & 0.056 & 4.14 & 0.096 & 4.66 & 0.057 & 5.42 \\
\hline 2001 & -0.044 & 3.15 & -0.039 & 3.75 & -0.024 & 2.90 \\
\hline 2002 & -0.033 & 2.36 & -0.019 & 1.78 & -0.012 & 1.40 \\
\hline 2003 & 0.036 & 2.50 & 0.032 & 2.61 & 0.014 & 1.51 \\
\hline 2004 & 0.149 & 10.16 & 0.135 & 10.31 & 0.104 & 10.62 \\
\hline 2005 & 0.193 & 12.25 & 0.153 & 9.69 & 0.136 & 12.40 \\
\hline 2006 & 0.247 & 14.97 & 0.177 & 11.34 & 0.168 & 15.97 \\
\hline 2007 & 0.250 & 14.76 & 0.160 & 9.54 & 0.162 & 14.83 \\
\hline 2008 & 0.174 & 10.84 & 0.088 & 5.16 & 0.105 & 8.48 \\
\hline Germany & -0.036 & 1.86 & 0.101 & 11.49 & 0.097 & 9.89 \\
\hline UK & 0.053 & 1.63 & -0.006 & 0.54 & 0.069 & 3.80 \\
\hline Sweden & -0.354 & 9.48 & -0.033 & 2.87 & -0.042 & 2.31 \\
\hline Constant & 4.429 & 11.76 & 1.339 & 6.41 & 2.998 & 10.87 \\
\hline Industry controls & yes & & Yes & & Yes & \\
\hline Dependent variable & $\log \mathrm{V} / \mathrm{L}$ & & $\log V / L$ & & $\log V / L$ & \\
\hline Estimation method & GMM & & GMM & & GMM & \\
\hline No observations & 6628 & & 7776 & & 8077 & \\
\hline $\mathrm{AR}(2)$ test & 1.09 & & 1.66 & & 0.57 & \\
\hline & $(0.294)$ & & $(0.092)$ & & $(0.569)$ & \\
\hline Sargan test & 49.06 & & 39.08 & & 26.24 & \\
\hline & $(0.218)$ & & $(0.382)$ & & $(0.855)$ & \\
\hline
\end{tabular}

Note: Coefficients in bold are significant at $1 \%$ level or better. 
Table 3b: Empirical models of labour productivity growth (regulation)

\begin{tabular}{|c|c|c|c|c|c|c|}
\hline \multirow{2}{*}{ Variable } & \multicolumn{2}{|c|}{ Small firms } & \multicolumn{2}{|c|}{ Large firms } & \multicolumn{2}{|c|}{ All firms } \\
\hline & Coeff. & Z-score & Coeff. & Z-score & Coeff. & Z-score \\
\hline Lagged Log V/L & 0.100 & 7.41 & 0.538 & 9.29 & 0.161 & 5.89 \\
\hline $\mathrm{K} / \mathrm{L}$ change & 0.036 & 6.02 & 0.050 & 7.62 & 0.025 & 4.49 \\
\hline Log Firm age & 0.018 & 1.68 & -0.105 & 6.71 & 0.067 & 5.45 \\
\hline Log Sales & 0.106 & 9.76 & 0.119 & 9.12 & 0.114 & 7.59 \\
\hline $\log C / E$ & 0.063 & 5.64 & 0.079 & 5.81 & 0.048 & 7.14 \\
\hline 2001 & -0.072 & 4.37 & -0.066 & 5.61 & -0.042 & 4.57 \\
\hline 2002 & -0.045 & 2.67 & -0.043 & 3.60 & -0.022 & 2.41 \\
\hline 2003 & 0.028 & 1.66 & 0.009 & 0.76 & 0.013 & 1.45 \\
\hline 2004 & 0.113 & 6.34 & 0.107 & 8.42 & 0.101 & 7.60 \\
\hline 2005 & 0.125 & 6.74 & 0.112 & 7.42 & 0.140 & 10.70 \\
\hline 2006 & 0.168 & 8.77 & 0.135 & 8.59 & 0.171 & 13.40 \\
\hline 2007 & 0.160 & 8.22 & 0.111 & 6.61 & 0.160 & 12.24 \\
\hline 2008 & 0.135 & 7.09 & 0.041 & 2.45 & 0.108 & 8.43 \\
\hline Factor & 0.028 & 2.43 & 0.039 & 7.83 & 0.034 & 6.43 \\
\hline Constant & 2.062 & 10.35 & 0.781 & 6.71 & 2.300 & 10.92 \\
\hline Industry controls & yes & & Yes & & Yes & \\
\hline Dependent variable & $\log \mathrm{V} / \mathrm{L}$ & & $\log \mathrm{V} / \mathrm{L}$ & & $\log \mathrm{V} / \mathrm{L}$ & \\
\hline Estimation method & GMM & & GMM & & GMM & \\
\hline No observations & 6628 & & 7776 & & 8077 & \\
\hline $\mathrm{AR}(2)$ test & 0.47 & & 0.79 & & 0.26 & \\
\hline & $(0.636)$ & & $(0.430)$ & & $(0.798)$ & \\
\hline Sargan test & 10.26 & & 36.54 & & 40.53 & \\
\hline & $(0.999)$ & & $(0.583)$ & & $(0.403)$ & \\
\hline
\end{tabular}

Note: Coefficients in bold are significant at $1 \%$ level or better. 
Table 3c: Empirical models of labour productivity growth (regulation)

\begin{tabular}{|c|c|c|c|c|c|c|}
\hline \multirow{2}{*}{ Variable } & \multicolumn{2}{|c|}{ Small firms } & \multicolumn{2}{|c|}{ Large firms } & \multicolumn{2}{|c|}{ All firms } \\
\hline & Coeff. & Z-score & Coeff. & Z-score & Coeff. & Z-score \\
\hline Lagged Log V/L & 0.062 & 2.23 & 0.303 & 9.87 & 0.122 & 4.62 \\
\hline $\mathrm{K} / \mathrm{L}$ change & 0.027 & 4.85 & 0.041 & 7.39 & 0.021 & 4.01 \\
\hline Log Firm age & 0.030 & 2.59 & -0.047 & 3.18 & 0.013 & 0.91 \\
\hline Log Sales & 0.021 & 1.10 & 0.080 & 7.12 & 0.035 & 2.87 \\
\hline $\log C / E$ & 0.104 & 7.17 & 0.077 & 6.25 & 0.049 & 4.61 \\
\hline 2001 & -0.039 & 1.99 & -0.081 & 5.88 & -0.043 & 4.14 \\
\hline 2002 & -0.014 & 0.54 & -0.105 & 5.92 & -0.052 & 3.68 \\
\hline 2003 & 0.054 & 2.11 & -0.050 & 2.58 & -0.039 & 2.43 \\
\hline 2004 & 0.105 & 4.06 & 0.046 & 2.35 & 0.058 & 3.62 \\
\hline 2005 & 0.138 & 5.25 & 0.063 & 3.04 & 0.086 & 5.14 \\
\hline 2006 & 0.192 & 7.14 & 0.089 & 4.31 & 0.118 & 7.34 \\
\hline 2007 & 0.186 & 6.90 & 0.072 & 3.40 & 0.108 & 6.59 \\
\hline 2008 & 0.120 & 4.52 & 0.002 & 0.09 & 0.050 & 2.81 \\
\hline Germany & -0.029 & 2.40 & 0.312 & 2.37 & 0.327 & 4.43 \\
\hline UK & 0.439 & 3.74 & 0.427 & 2.90 & 0.532 & 4.29 \\
\hline Sweden & 0.277 & 3.00 & 0.833 & 4.88 & 0.502 & 4.17 \\
\hline Factor & 0.407 & 1.41 & 0.215 & 1.85 & 0.371 & 3.35 \\
\hline Germany*Factor & -0.070 & 0.17 & 0.278 & 1.84 & 0.498 & 3.72 \\
\hline UK*Factor & -0.690 & 1.78 & -0.529 & 3.92 & -0.154 & 1.26 \\
\hline Sweden*Factor & -0.710 & 2.04 & -0.999 & 4.54 & -0.806 & 4.40 \\
\hline Constant & 2.438 & 8.55 & 1.961 & 4.68 & 2.728 & 9.18 \\
\hline Industry controls & yes & & Yes & & Yes & \\
\hline Dependent variable & $\log V / L$ & & $\log \mathrm{V} / \mathrm{L}$ & & $\log V / L$ & \\
\hline Estimation method & GMM & & GMM & & GMM & \\
\hline No observations & 6628 & & 7776 & & 8077 & \\
\hline $\mathrm{AR}(2)$ test & 1.75 & & 1.35 & & 1.26 & \\
\hline & $(0.080)$ & & $(0.177)$ & & $(0.208)$ & \\
\hline Sargan test & 37.73 & & 46.51 & & 44.23 & \\
\hline & $(0.528)$ & & $(0.191)$ & & $(0.260)$ & \\
\hline
\end{tabular}

Note: Coefficients in bold are significant at $1 \%$ level or better. 
Table 3d: Empirical models of labour productivity growth (Factor residuals)

\begin{tabular}{|c|c|c|c|c|c|c|}
\hline \multirow{2}{*}{ Variable } & \multicolumn{2}{|c|}{ Small firms } & \multicolumn{2}{|c|}{ Large firms } & \multicolumn{2}{|c|}{ All firms } \\
\hline & Coeff. & Z-score & Coeff. & Z-score & Coeff. & Z-score \\
\hline Lagged Log V/L & 0.065 & 2.48 & 0.279 & 9.36 & 0.139 & 5.42 \\
\hline $\mathrm{K} / \mathrm{L}$ change & 0.026 & 4.69 & 0.038 & 7.05 & 0.025 & 4.88 \\
\hline Log Firm age & 0.010 & 0.94 & -0.034 & 2.31 & 0.021 & 1.57 \\
\hline Log Sales & 0.056 & 3.56 & 0.066 & 5.92 & 0.026 & 2.22 \\
\hline $\log C / E$ & 0.076 & 5.90 & 0.055 & 4.53 & 0.026 & 3.06 \\
\hline 2001 & -0.151 & 7.65 & -0.129 & 9.03 & -0.104 & 9.09 \\
\hline 2002 & -0.149 & 7.12 & -0.133 & 8.62 & -0.109 & 8.83 \\
\hline 2003 & -0.073 & 3.36 & -0.098 & 5.73 & -0.095 & 7.19 \\
\hline 2004 & 0.052 & 2.63 & 0.027 & 1.71 & 0.030 & 2.48 \\
\hline 2005 & 0.083 & 4.11 & 0.042 & 2.45 & 0.056 & 4.28 \\
\hline 2006 & 0.135 & 6.52 & 0.071 & 4.17 & 0.090 & 7.00 \\
\hline 2007 & 0.133 & 6.37 & 0.054 & 3.09 & 0.078 & 6.04 \\
\hline 2008 & 0.076 & 3.68 & 0.020 & 1.13 & 0.018 & 1.28 \\
\hline Germany & -0.063 & 3.01 & 0.103 & 13.58 & 0.099 & 10.25 \\
\hline UK & -0.061 & 2.03 & -0.005 & 0.66 & 0.036 & 2.18 \\
\hline Sweden & -0.202 & 6.03 & -0.026 & 2.65 & -0.047 & 3.04 \\
\hline ResFactor & 0.180 & 2.05 & -0.025 & 1.66 & -0.012 & 0.60 \\
\hline Germany*ResFactor & -0.184 & 2.07 & 0.051 & 2.66 & 0.047 & 2.05 \\
\hline UK*ResFactor & -0.063 & 0.70 & 0.028 & 1.42 & 0.026 & 1.58 \\
\hline Sweden*ResFactor & -0.240 & 2.69 & -0.097 & 4.96 & -0.091 & 4.15 \\
\hline Constant & 2.965 & 7.83 & 2.170 & 4.37 & 2.966 & 9.32 \\
\hline Industry controls & yes & & Yes & & Yes & \\
\hline Dependent variable & $\log V / L$ & & $\log \mathrm{V} / \mathrm{L}$ & & $\log V / L$ & \\
\hline Estimation method & GMM & & GMM & & GMM & \\
\hline No observations & 6628 & & 7776 & & 8077 & \\
\hline $\mathrm{AR}(2)$ test & 1.45 & & 1.04 & & 0.62 & \\
\hline & $(0.147)$ & & $(0.298)$ & & $(0.531)$ & \\
\hline Sargan test & 38.96 & & 37.56 & & 25.76 & \\
\hline & $(0.472)$ & & $(0.536)$ & & $(0.949)$ & \\
\hline
\end{tabular}

Note: Coefficients in bold are significant at $1 \%$ level or better. 


\section{Notes}

1

Such policies have often been produced against the background of concern about levels of unemployment and hence have focussed attention on the role that labour market flexibility can play in increasing job creation. However, notwithstanding this, they invariably also focus attention on its role in increasing competitiveness (see e.g. European Commission, 2007 and 2009; OECD, 1994; Heyes, 2013: 72). This twin focus is of course unsurprising given the potential relevance of economic performance to employment growth. It does though co-exist with some evidence suggesting the existence of a trade of between trends in labour productivity and employment growth (see e.g. Storm and Naastepad, 2007: 15-16).

2

On the last point, also see Traxler and Kittel (2000). More generally, it should be noted that the questionable empirical validity of the OECD's prescriptions for job creation exist alongside evidence indicating that deregulated (and decollectivized) labour markets generate a number of adverse social outcomes, including greater income inequality, poorer job quality and lower life satisfaction. See e.g. Frege and Goddard (2014), and Cazes et al (2012).

3

For a valuable more general review of the economic evidence on the relationship between labour market flexibility and performance see Reed (2010).

4

Stronger evidence exists pointing to employment protection legislation impacting negatively on job flows between different parts of the economy. Such an impact could potentially have adverse consequences for productivity in contexts where it is largely driven by the reallocation of workers and investment from low- to high-productivity sectors, rather than through within-sector improvements. See Reed (2010: 105 and 139).

5

Both of the studies quoted in this paragraph use the term 'co-ordinated market' on the basis of the distinction drawn by Hall and Soskice (2010) between liberal market economies, in which firms coordinate their activities primarily via competitive markets and internal hierarchies, and co-ordinated ones, where firms depend more on non-market relationships to co-ordinate their activities.

6

The idea of including in Factor information on both the strictness of employment protection and trade union density is to capture broader, direct and indirect, impacts of EPL on behaviour in the labour market and the productivity of firms. The creation and implementation of labour laws is influenced by social relations in the economy captured by the dialogue between employers and employees (represented by trade unions); in some countries there could be tripartite framework where the government also plays a role. Furthermore, trade unions can be seen as important institutional mediator of the impact of EPL in the labour market. In any case, having some information on the employee voice and influence in the labour market included in the Factor variable would allow for better capturing the real effects of EPL in our analysis. We note, however, that we have also experimented with only the strictness of employment protection information included in Factor and the results are qualitatively similar.

7

The factor generated through factor analysis and applied to the sample of our four countries over the period of ten years (1999-2008) is a standardised variable with mean zero and standard deviation one.

8

The TOP-1.5-million AMADEUS module contains firms which must satisfy one of the following criteria: i) operating revenue $>€ 1$ million; ii) total assets $>€ 2$ million; iii) number of employees $>15$. There is also a TOP-250,000 module which contains only large firms which must satisfy one of the following criteria: i) operating revenue $>€ 10$ million; ii) total assets $>€ 20$ million; iii) number of employees $>150$. Financial information is reported from unconsolidated firm financial statements. We note, however, that for some firms information is incomplete or available only for a single year. 
9

Estimation results where we change our assumption of exogeneity of variables are similar to the ones reported and are available on request.

${ }^{10}$ Because ResFactor is by construction orthogonal to the country effects we treat it in our GMM estimation as predetermined variable. Results from an estimation where we treat ResFactor as endogenous variable are similar to the ones reported.

11

The authors thank one of the anonymous referees for drawing their attention to this paper.

${ }^{12}$ Generally, we do not observe TFP directly. This problem is addressed by the traditional growth accounting method, which has its theoretical underpinnings in the neoclassical growth model. Under the assumption that all markets function perfectly, the growth accounting method permits changes in TFP to be calculated as a residual having subtracted changes in inputs from output growth. There are various methods (e.g., Van Biesebroeck, 2008) that are often employed to estimate TFP.

${ }^{13}$ An alternative approach is to start with gross output (gross value added plus purchases) and include purchases as intermediate inputs in the above formulae. As our goal is to provide a simple framework for understanding the channels through which employment regulation may impact labour productivity we choose the value added formulation. 